\title{
Socio-Legal Study of Community Participation in Restorative Justice of Children in Conflict with the Law in Indonesia
}

\author{
Nur Rochaeti* and Nurul Muthia
}

Faculty of Law, Diponegoro University, Semarang, Indonesia

\begin{abstract}
The state has the obligation and authority to protect children. This is regulated in Article 28 of the 1945 Constitution of the Republic of Indonesia, that everyone has the right to just recognition, guarantee, protection, and legal certainty as well as equal treatment before the law, namely that the State is obliged to protect every citizen regardless. The problem in this paper is how is the socio-legal study of restorative justice in the Juvenile Criminal Justice System in Indonesia. The method used in this research is a socio-legal research approach. This study found that the customary institution in Padang, West Sumatra is factually recognized in its existence in the customary criminal law of the Dua Puluah Customary Law. Moreover, the results showed that particularly in regulating the provisions of the material criminal law, in the Salapan Law (eight), and the Kanayatn Dayak community. implementing the restorative justice mechanism is resolved by deliberation and is family in nature in a Barukupm Adat forum, which involves all parties, both from functionaries, children of perpetrators and their families, victims and their families as well as witnesses who know the case, and pay attention to the rights of community members within the boundaries the agreed boundaries to be obeyed, based on the values and norms that exist in society. This study offers relevance in the context of non-legal settlement in cases of restorative justice in cases of children in conflict with the law in Indonesia. This study underscores expediency to provide greater space for customary entities to resolve children's cases non-legally and to increase community participation in the resolution of legal cases involving children.
\end{abstract}

Keywords: Socio-legal, Community Participation, Restorative Justice, Children in Conflict with the Law, Indonesia.

\section{INTRODUCTION}

In Indonesia, the 1945 Constitution, Article 28 B paragraph (2) states that every child has the right to survive, grow and develop and has the right to protection from violence and discrimination, meaning that the state, society, and parents should provide respect and protection for children without discrimination. The state has obligation and authority to protect children as regulated in Article 20 of Law Number 35 of 2014 concerning Amendments to Law Number 23 of 2002 concerning Child Protection, "The state, government, local government, community, family, and parents or guardians are obliged and responsible for the implementation of child protection." Every child has the right to receive protection from the time he is in the womb until he becomes an adult and children have rights that are specifically different from adult human rights.

To protect children, not only with the "legal substance", but it also needs to be supported by the strengthening of the "legal structure" and "legal culture". Juridical, in Law No. 11 of 2012 concerning the Criminal Justice System for Children, it is explained how the judicial process for children in conflict with the law. In-Law No. 35 of 2014, amended from Law No. 23

*Address correspondence to this author at the Faculty of Law Diponegoro University, JI. Prof. Soedarto, S.H. Tembalang, Semarang 50275, Indonesia; Tel: +62-2476918201; Fax: +62-247691820

E-mail: etikfh@live.undip.ac.id of 2002 concerning Child Protection, also explains how a child is entitled to protection and "special" treatment if the child is in an emergency such as a suspect in criminal acts, violence, exploitation and so on. This is also emphasized by the existence of rules in international law, namely the Convention on the Rights of the Child which explains the protection and "special" treatment of children in conflict with the law.

Handling children who are faced with the law in criminal justice still has several obstacles, namely the application of the law is not fully following the provisions of the applicable law; there is no common perception among law enforcement officials regarding the handling of Children in Conflict with the Law (ABH) in the best interests of the child; limited facilities and infrastructure for handling children in conflict with the law during the court process (pre and post court decisions); coordination between law enforcement officials (police, prosecutors, judges, advocates, detention centers, prisons), is still choked up due to sectorial ego constraints (Dewi \& Syukur, 2011).

Restorative justice is to recover losses and this relationship will be achieved through cooperative processes that include all interested stakeholders (Muladi, 2004). Philosophically, juvenile justice is not retaliation like the philosophy of adult justice, but in the framework of achieving children's welfare. Punishment for children who violate the law is not in the form of punishment but rather acts, which are not carried out at 
institutions under the Ministry of Law and Human Rights, but educational institutions under the Ministry of Social Affairs or under the Ministry of Women's Empowerment and Child Protection, even possible to be submitted to the community to guide a more nonpenal process. The problem in this study is the sociolegal study of community participation in restorative justice in Indonesia. The paper aims to investigate restorative justice as a theory and a practice that emphasizes restoring losses and damaged relationships caused or inflicted by criminal acts, especially by exploring the role of community participation through local wisdom in resolving the cases of children in conflict with the law in Indonesia. The objectives of this study are to explore restorative justice as it is needed as a form of overcoming delinquency that pays more attention to the special needs of children. Moreover, handling juvenile justice through restorative justice is an option to cover weaknesses and dissatisfaction with the retributive and rehabilitative approaches that have been used in the criminal justice system in general.

\section{METHOD}

The method used in this research is a socio-legal research approach (Hutchinson, 2006). Based on this approach, community participation will be found in the juvenile justice system in Indonesia, also that, there will also be obstacles in the handling of children related to restorative justice at the Customary Institution in West Sumatra and the Dayak Kanayatn community of West Kalimantan.

More specifically, by examining the method used in this research of a socio-legal research approach, the method used in this research is the socio-legal research approach, which is a study that examines law as a social fact that can be seen in the realm of experience as a pattern of behavior in the form of social institutions or social institutions, legal studies that conceptualize and theorize law as social facts. positive and empirical. As noted by Hutchinson (2006), there are 2 aspects to the socio-legal research approach. The first aspect of Legal Research is the object of research in the form of law in the sense of "norms" of legislation, and the second is socio research, namely the use of social science methods and theories related to law to assist researchers in conducting the analysis.

The data collection technique was carried out directly to the field by interviewing the customary head (datuak) in Padangpariaman and one of the timanggong (village head) of the Dayak Kanayatn tribe. Based on this approach, community participation in the juvenile criminal justice system will be found as well as obstacles in handling children related to restorative justice at the Nagari Adat Population Institution in Padangpariaman, West Sumatra and the Kanayatn Dayak community in West Kalimantan.

\section{RESULT}

As a research object of this study, Minangkabau society as a society that has religious characteristics (adherents of the Islamic religion), basandi sarak baandi Kitabullah. The Minangkabau people in social and community life have very strong and institutional signs and handles called "Tali Tigo Sapilin", also based on the noble teachings that are organized and taught in everyday life, namely the four teachings of goodness (Tau Jo Nan Ampek) always holding on to institutionalization in his life. In daily life, the Minangkabau people use traditional language, especially those related to the view of life and norms in community life, which is expressed in the form of the "petitih mamang" proverb, expressions of expression, and others.

According to Rasyid Manggis Dt. Rajo Panghulu (1982), "adat" comes from the Sanskrit word a and dato, "A" means no, "dato" means something that is material. "Adat" is anything that is not material, even though there are differences in interpretation, both have the same goal of regulating the order of community life, both individually and collectively in every behavior and deeds in association based on good character, so that each individual is capable. Feel in him what others feel, as the saying goes "Bak adat bapiek kulik, Sakik dak awak sakik dek urang, nan elok dek awak katuju dek urang". Custom is nothing but spiritual perfection. Custom is cannot be measured with the five senses, apart from the five senses, which is the psychological sense (Panghulu, 1991).

There is an intersection (linkage) of philosophical roots between the Minangkabau tradition which originates from the truth and the nature of takabang as a teacher, where the teachings take an overview of the provisions of the universe, namely: "Alam takabang jadikan guru, Satitiak jadikan lauik, Sakapa jadikan gunuang". In connection with Minangkabau tradition, custom is based on a person's character, so the word dignity is used such as dignity which should be used by the leader. The word law is used to mean the legal 
settlement process, such as bainah law, karinah law, ijtihad law, and science law. From the information above, the meaning of being close together contains the meaning of the rules that will guide someone in the life of the world (Panghulu, 1982).

The meaning of the Minangkabau customs means bapucuak sabana bulek, basandi sabana pandek, (tip round, jointed solid/strong). This means that the Minangkabau people are devoted to God whose teachings are expressed in the Koran and are implied in the Alama (Alama takambang jadi guru) The conditions that support such Minangkabau customs also originate from the meaning of words (idioms) commonly used, moral sanctions, behavior, temperament, rules, dignity, law, guidance, habits, barih balabeh, reason, mind, shame and so on (Panghulu, 1991).

The settlement of customary problems at the Nagari Adat Kerapatan Institution is resolved in an online manner bajanjang naiak batanggo turun, the point is a settlement from below between the victim and the perpetrator tries to solve the problem by deliberation, if the deliberation does not reach consensus or it does not work, then it is submitted to Nagari. Nagari through the Nagari Adat Kerapatan Institute, whose process is the chairman of the Nagari Kerapatan Adat, collects and calls on all Niniak Mamak in Nagari and this is where legal problem resolution occurs, the settlement of legal problems in Nagari is mediation involving a third party as a mediator in Nagari is datuak, who helps victims and perpetrators to reach a conflict resolution that is accepted by both parties, then if the process is not completed in Nagari it will be brought to the realm of law by Indonesian positive law. When a person commits a criminal act and the settlement is not completed at the Nagari customary density institution, it continues to the litigation process, when the litigation process has been completed and received a judge's verdict such as imprisonment and has been executed by the perpetrator then when he returns to society, the perpetrator still gets Guidance from the Nagari Adat Density Institution, especially niniak mamak, shows the role of the Nagari Adat Density Institution. The meaning of the Minangkabau costums means bapucuak sabana bulek, basandi sabana pandek, (tip round, jointed solid/strong). This means that the Minangkabau people are devoted to God whose teachings are expressed in the Koran and are implied in the Alama (Alama takambang jadi guru) The conditions that support such Minangkabau customs also originate from the meaning of words (idioms) commonly used, moral sanctions, behavior, temperament, rules, dignity, law, guidance, habits, barih balabeh, reason, mind, shame and so on (Panghulu, 1991).

In Minangkabau custom, corporal punishment is not common, in Minangkabau it is only punishable by virtue. Minangkabau people live in kinship, so it is an insult to someone when they are expelled from family relationships. Hina is a punishment that is not restrained by the soul of the Minangkabau people, as reflected in the proverb which states " nan sakik kato, nan malu tampak". The point is that the Minang people cannot stand humiliation kato tasinggung labiah bak kanai (Panghulu, 1991). Minang people are embarrassed when the mind is seen. That is why each family puts ameh in the house to keep a family from getting embarrassed. In the Minangkabau Indigenous Community has a sufficiently complete legal institution both in substance and structure, both formal and material laws.

In the Kapalo Koto area, Padang Pariaman, the types of cases of children committing a criminal offense, namely, abuse, theft, violence. The settlement of criminal cases at the Nagari Kapalo Koto Customary Population Institution carried out by children, the mechanism for handling them is the same as bajanjang naiak batanggo turun. The sanctions will be imposed in accordance with the agreement, such as the payment of fines according to the offender's mistakes, these fines are for the interests of Nagari and social sanctions. Determination of the weight or lightness of this sanction depends on the mistakes made by the perpetrator. In the imposition of customary sanctions, sometimes there are obstacles faced, namely the parties do not receive the sanctions imposed, then this case will baliak ka ateh, namely returning to the authorities.

Furthermore, the results of research in the Kanayatn Dayak Community which have a territorial unit called Binua. Binua is an area consisting of several villages (formerly Radakng/Bantang). Each Binua has its autonomy so that one Binua community cannot interfere with the customary law in another Binua. Each Binua is led by a Timanggong (village head). Timanggong has subordinate ranks, namely Pasirah (customary administrator) and Pangaraga (customary lawyer). The blood system of the Kanayatn Dayak tribe uses the bilineal/parental system (father and mother). In breaking down kinship relationships, a child can follow the path of both father and mother. The kinship 
was cut off on cousins eight times. This kinship relationship is important because this relationship is a review, especially in marriage cases. Maybe this is meant so as not to damage the offspring.

In West Kalimantan the oral tradition of the Dayak Kanayatn is the same as the customs that apply in their lives. This custom covers all aspects of life and affects people's lives. It regulates people's lives in interaction. When the Kanayatn Dayak people violate customary law, they are more embarrassed than they are breaking government regulations. This is because the custom is a universal and binding rule of ancestral heritage. Not respecting custom is considered "not cultured". If the Kanayatn Dayak people are not civilized, then it can be equated that they are not Dayak people. Things like this are why oral and customary traditions are highly respected and upheld in the life of the people. The oral traditions of the Dayak Kanayatn are closely related to ceremonies. Social arrangements, behavior, and ceremonies in the Kanayatn Dayak community are regulated by custom and there are sanctions for any violations.

Through this tradition, all forms of ceremony and music in the ceremony can be preserved. This means that the custom or oral tradition of the Dayak Kanayatn requires a ceremony, while the ceremony is closely related to music as part of the ceremony. The oral traditions of the Kanayatn Dayak people are part of a myth related to belief. These myths explain a sacred event or an event experienced by ancient ancestors. The ancient times were holy and at that time there was still a meeting with the divine. All these myths become the basis of behavior to support social stability in society. People respect myths because customs were born from these myths. Naturally, some people consider myth to be the holy book of the Dayak Kanayatn people, even for all Dayak communities in Kalimantan. The oral tradition of the Dayak Kanayatn is divided into two parts, namely those with narrative patterns, such as folk tales, legends, epics, and those with non-story patterns, such as expressions, singing oral poetry, rules, and traditional ceremonies. In the Kanayatn Dayak Custom Management Structure. First, Pangaraga, whose main task is to handle disputes in the village, its authority is to accept every complaint from its community members and to resolve customary matters regarding minor cases. Secondly, Pasirah, The authority is to accept the delegation of authority from the Temenggung Binua assisted by the Pangaraga to resolve every kind of minor case submitted by the community, if not resolved then the case is forwarded to the Timanggong accept the decision Pangaraga and Pasirah. Apart from that, the main task is to handle serious cases, such as murders, mass fights, and attacks from Binua or other villages. Customary procedures for punishment sanctions for wrongdoing by a person/group of people in the customary community concerned, there is, for example, the custom of firebrick, the custom of balaki-babini sakamarkapala. Penalties or sanctions are imposed in the form of goods (plates, machetes, gongs) and animals, especially chickens and pigs. However, now it has begun to change a little by using replacement money for goods. This is due to the difficulty in obtaining these items.

Legal life in the community can be resolved according to custom as long as there is an agreement from both parties. They prefer to resolve disputes or legal problems customarily employing traditional ceremonies and with customary fines which vary considerably depending on the size of the error, whether or not the result of a legal event is serious. Fines can be in the form of money or pets, although sometimes they are quite large with or with sanctions that must be borne, the customary settlement is still the main alternative because, in the process of the ceremony, prayers are carried out by prayer experts with the aim that there is forgiveness and settlement can run peacefully, especially after a legal event occurs. Family relations after traditional ceremonies and settlement of fines, among those who conflict or trouble can be peaceful and live side by side again without any revenge. This is what they feel with customary solutions.

\section{DISCUSSION}

Restorative justice has evolved from a belief that traditional justice systems have done little to involve communities in the process of dealing with crimes and committing wrongdoing. What has been developed is a system of coercive penalties, administered by bureaucrats, that is harmful to offenders and likely reduces the likelihood that the offender will later become productive members of society. This system relies on punishment, stigma, and shame (Siegel, 2010). The role of society in restorative justice in each region has values, habits, norms that will be enforced in maintaining harmony between community members, in this case, the perpetrator and his family, victims and their families, and other community members. The plurality of Bhineka Tunggal lka is characteristic of Indonesia with many islands, ethnicities, languages, 
and cultures, Indonesia wants to build a stable and modern nation with strong national ties. So that avoiding pluralism is tantamount to avoiding different realities regarding the perspectives and beliefs that live in Indonesian society. Pluralism can be horizontal, that is, subcultures or subsystems have equal legitimacy status, or vertically, arranged hierarchically where there is a "higher" and "lower" legal system or culture (Friedman, 1975).

According to Hippy (2012), several things are more desired by the community, namely not on the aspect of law enforcement alone but rather on the values of peace and public peace, because in essence settlement through law/court will not resolving problems, sometimes even resulting in conflict and displeasure between members of the community who litigate. A restorative justice system is an option that is considered to be able to resolve a criminal case, namely because: First, it provides an immediate benefit to the victim, the perpetrator, and the general public. Second, the mechanism for resolving criminal cases using the restorative justice approach plays a big role in the community, namely as a supervisor and monitoring implementation based on the agreement of the parties in litigation. Third, the process of handling cases with a restorative justice approach can be carried out quickly and precisely, this is because it does not go through a convoluted process (Zulfa, 2011).

In the development of the National Law System, Pancasila is the ideological and philosophical basis for implementing a restorative justice system, which is based on religious, human, and social values. Provide the rights of victims and perpetrators without neglecting traditional or religious values in society. One of pluralism in Indonesia is customary justice as an important part of the development of the philosophy of the restorative justice process, which is derived from the values of indigenous peoples that have existed so far.

The findings of this study were in line with Bazemore (1998) suggesting the need for a shift towards a restorative approach in juvenile justice. Moreover, in line with the need for increasing community participation in restorative justice, Bazemore (1998) proposes the main points of thought in the restorative paradigm to pay attention to the aspects of community protection. The assumptions in restorative justice regarding achieving community protection by collaborating efforts of the justice system and society to develop prevention, confinement is limited to only a last resort.

The findings also noted the explanation of Braithwite (2004) expressing ways to create feelings of shame and personal and family responsibility for their wrongdoing to be adequately corrected. This is based on the perspective that restorative justice intends to restore the welfare of the community through ways of holding children's behavior to accountability for their behavior and that victims are allowed to participate in the process (Hagan, 2002).

The settlement for juvenile justice as found in Minangkabau and Dayak societies was also in line with the theoretical perspectives proposed by Van Ness \& Nolan (1998) regarding the restorative justice to simplify the process that a child who conflicts with the law must go through; protect the rights of victims and perpetrators; minimize the negative impact on the criminal justice process that has been undertaken for children in conflict with the law, and involve community participation in law enforcement. These findings also support Davies \& Robson (2016) and Trihastuti \& Putri (2020) that specifically underlines the importance of repositioning children's rights in various legal cases through the application of fair juvenile courts. Lastly, the findings denote the importance of local wisdom and recognition of legal pluralism in juvenile justice that deemed capable of providing nonlegal measures in juvenile justice cases in their decision (Griffiths 1986; Masinambow, 2003; Menski, 2006; Friedman, 1975; Nasikun, 1974; Riggs (1964; Levin \& Nave 2007; Zulfa, 2011). It also denoted the importance of participation of community and customary laws in the juvenile justice system, especially in Indonesia with its various traditional legal systems (Soemitro, 1985; Hart 1966; Suteki, 2007; van Apeldoorn, 1958). Theoretically, society is interpreted as a form of living arrangement that is more or less independent, is an orderly pattern of relationships between individuals who live together who have certain independent realities and objectives vis a vis the members of the group concerned (Steeman, 1973; Braithwite, 2004).

\section{CONCLUSION}

The findings showed the relevance of restorative justice application in juvenile justice conducted by some customary societies with the National Law instrument as a legal aspect, namely Law no. 11 of 2012 concerning the Juvenile Criminal Justice System which has been regulated on the juvenile criminal 
justice system which involves various subsystems, namely the police, prosecutors, courts, lawyers, the existence of crimes and actions, and has regulated the obligation to implement restorative justice, diversion, and community participation.

The findings provide the prospect for denoting the importance of the sociological aspect of restorative justice in Indonesia by deepening the community participation that has legal and cultural characteristics, moral values, religion in resolving problems by deliberation. Practically, the findings showed that the resolution mechanism is following the applicable customary law process and combines the criminal justice mechanism with community participation, in deliberation mediation. To obtain an agreement between the victims, the perpetrator, the victim's family, the perpetrator's family, and the parties related to the case. The existence of restorative justice in the customary institution in Padang, West Sumatra, currently and Minangkabau is factually recognized in its existence in the Customs Criminal Law of the Dua Puluah Customary Law, particularly in regulating the provisions of material criminal law, namely the Salapan Law (eight). In the law nan salapan (eight) there are even criminal sanctions that are not only imposed on perpetrators (individuals) but also on groups (members of tribes/clans), especially for criminal sanctions being excluded from customary density.

The limitation of this study lies in the lack of customary law as the object. Future studies are expected to expand the scope of socio-legal studies in the field of customary law in juvenile justice through restorative justice in various societies.

\section{REFERENCES}

Apeldoorn, L. J. (1958). Pengantar ilmu hukum. Noordhoff-Kolff.

Bazemore, G. (1998). Restorative justice and earned redemption: Communities, victims, and offender reintegration. American behavioral scientist, 41(6), 768-813. https://doi.org/10.1177/0002764298041006003

Braithwite, J. (2004). Restorative Justice: Assessing an Immodest Theory and a Pessimistic Theory Draft to be summited to Crime and Justice: Review of Research.

Davies, S. G., \& Robson, J. (2016). Juvenile (In) justice: Children in Conflict with the Law in Indonesia. asia-pacific journal on human rights and the law, 17(1), 119-147. https://doi.org/10.1163/15718158-01701009
Dewi, D. S., \& Syukur, F. A. (2011). Mediasi Penal: Penerapan Restorative Justice di Pengadilan Anak Indonesia. Indie Pub..

Friedman, L. M. (1975). The legal system: A social science perspective. Russell Sage Foundation.

Griffiths, J. (1986). What is legal pluralism?. The journal of legal pluralism and unofficial law, 18(24), 1-55. https://doi.org/10.1080/07329113.1986.10756387

Hagan, F. E. (2002). Criminology Today. Washington DC: Wadsworth Group.

Hart, D. M. (1966). A Customary Law Document from the Ait' Atta of the Jbil Saghru. Revue de l'Occident Musulman et de la Méditerranée (ROMM), 90-112.

Hippy M. R.. (2012). Memperkenalkan Kajian Sosio-Legal dan Implikasi Metodologisnya, in Sulistyowati Irianto (Eds), Kajian Sosio-Legal. Denpasar: Pustaka Larasan.

Hooker in Masinambow, E. K. M. (2003). Hukum dan Kemajemukan Budaya. Jakarta: Yayasan Obor Indonesia.

Hutchinson, T. C. (2006). Researching and writing in law. Thomson Lawbook Co.

Levin, M., \& Nave, C. P. (2007). Tensor renormalization group approach to two-dimensional classical lattice models. Physical review letters, 99(12), 120601. https://doi.org/10.1103/PhysRevLett.99.120601

Menski, W. F. (2006). Comparative law in a global context: the legal systems of Asia and Africa. Cambridge University Press. https://doi.org/10.1017/CBO9780511606687

Muladi, L. (2004). Kapita Selekta Hukum Pidana Kriminologi dan Viktimologi. Jakarta: Djambatan.

Nasikun, J. (1974). Sebuah pendekatan untuk mempelajari sistim sosial Indonesia (No. 2). Seksi Penerbitan Fakultas Sosial dan Politik, Universitas Gadjah Mada.

Panghulu, M. R. M. D. R. (1982). Minangkabau, sejarah ringkas dan adatnya. Mutiara.

Penghulu, M. D. R. (1991). Bahasa orang cerdik pandai Minangkabau.

Rahardjo, S. (2005). Hukum Adat Dalam Negara Kesatuan Republik Indonesia (Perspektif Sosiologi Hukum). Paper presented at the Customary Law Workshop organized by the Constitutional Court, 4-6.

Riggs, F. W. (1964). Administration in developing countries: The theory of prismatic society. Houghton Mifflin.

Siegel, L. J. (2010). Criminology: The core. Nelson Education.

Soemitro, R. H. (1985). Beberapa Masalah dalam Studi Hukum dan Masyarakat. Bandung: Remadja Karya.

Steeman, T. M. (1973). Religious Pluralism and National Integration. Cambridge, MA: Harvard University,

Suteki. (2007). Integrasi Hukum Dalam Masyarakat. Semarang: Pustaka Magister.

Trihastuti, N., \& Putri, S. A. (2020). Reposition of child protection through the enforcement of human rights and constitutional rights. Jurnal Hukum dan Peradilan, 9(2), 314-335. https://doi.org/10.25216/jhp.9.2.2020.314-335

Van Ness, D. W., \& Nolan, P. (1998). Legislating for restorative justice. Regent UL Rev., 10, 53.

Zulfa, E. A. (2011). Pergeseran paradigma pemidanaan. Lubuk Agung.

DOI: https://doi.org/10.6000/1929-4409.2021.10.35

(C) 2021 Rochaeti and Muthia; Licensee Lifescience Global.

This is an open access article licensed under the terms of the Creative Commons Attribution Non-Commercial License (http://creativecommons.org/licenses/by-nc/3.0/) which permits unrestricted, non-commercial use, distribution and reproduction in any medium, provided the work is properly cited. 